\title{
Pemberdayaan Koperasi Unit Desa Melalui Analisis Faktor-Faktor Kunci Manajemen
}

\author{
Sulistyo Sidik Purnomo dan Briljan Sudjana \\ Fakultas Pertanian Universitas Singaperbangsa Karawang \\ Jl. H.S. Ronggowaluyo-Telukjambe, Karawang 41361 \\ Korespondensi : psulistyosidik@yahoo.co.id
}

\begin{abstract}
Empowerment of Koperasi Unit Desa through Management Key Factors Analysis Koperasi Unit Desa (KUD) is rural insitution which has important role in agricultural develompent. However, nowadays KUD is not totally independent because of intensive government intervention especially to carry out rural development programs in agriculture. The aim of this study was to identify several major key factors that influence KUD management and to determine effect of those key factors on KUD's independence. Study was carried out in 10 KUD in Garut district, which are succes to develop KUD in nasional level. Study was conducted through the field survey using questionnaire as a tool to collect primary data. Collected data were analysed by using Structural Equation Modelling (SEM) to find the extent of endogenous- as well as exogenous-latent key factors on KUD management. Analysis of key variables showed that 15 endogenous latent factors as well as 80 exogenous one were the key factors in good-managed KUD. All of those factors are recommended to be applied as a guide in efforts towards the empowerment of the independent $K U D$.
\end{abstract}

Key words: Endogenous and exogenous latent factor, Koperasi Unit Desa, Management

\begin{abstract}
ABSTRAK
Koperasi Unit Desa (KUD) adalah lembaga pedesaan yang memiliki peran penting dalam pembangungan pertanian. Namun saat ini kemandirian KUD belum kuat karena KUD masih merupakan kepanjangan tangan pemerintah untuk melaksanakan program pembangunan pedesaan terutama di sektor pertanian. Penelitian bertujuan untuk mendapatkan faktor-faktor kunci manajemen KUD serta menentukan besar pengaruh masing-masing faktor tersebut terhadap kemandirian KUD. Penelitian dilakukan terhadap 10 KUD Kabupaten Garut yang berhasil mengembangkan KUD di tingkat nasional melalui survai lapangan dengan bantuan kuesioner untuk mendapatkan data primer. Data yang terkumpul dianalisis dengan menggunakan Structural Equation Modelling (SEM) untuk menentukan besarnya pengaruh faktor kunci berupa faktor laten endogen dan eksogen terhadap keberhasilan dalam manajemen KUD. Analisis variabel-variabel yang diteliti menghasilkan 15 faktor kunci laten endogenous dan 80 faktor kunci latent exogenous. Seluruh faktor kunci tersebut direkomendasikan untuk digunakan sebagai pedoman dalam upaya pemberdayaan KUD ke arah kemandirian.
\end{abstract}

Kata kunci: Faktor laten endogen dan eksogen, Koperasi Unit Desa, Manajemen. 


\section{PENDAHULUAN}

Salah satu lembaga yang memiliki peranan penting dalam pembangungan pertanian adalah Koperasi Unit Desa (KUD). Undang-undang Nomor 25 Tahun 1992 tentang Perkoperasian menjelaskan bahwa koperasi adalah sokoguru untuk memperkokoh perekonomian rakyat. Fungsi strategis tersebut menuntut adanya koperasi yang berperan secara aktif dalam upaya mempertinggi kualitas kehidupan manusia dan masyarakat.

Menurut Nasution (2002), harapan terciptanya efisiensi ekonomi yang didasari efisiensi sosial merupakan sifat positif koperasi. Koperasi Unit Desa dibentuk sebagai wadah penggerak peranan dan tanggung jawab petani dalam rangka mengembangkan diversifikasi usahanya. Namun sampai saat ini posisi KUD sebagai lembaga ekonomi pedesaan masih merupakan kepanjangan tangan pemerintah untuk melaksanakan program pembangunan pedesaan terutama di sektor pertanian. Pemberdayaan KUD perlu diarahkan kepada perwujudan KUD yang mandiri dan berdaya saing di antara pelaku ekonomi lainnya.

Upaya pemberdayaan KUD dapat dilakukan melalui identifikasi dan analisis hubungan sebabakibat antara faktor-faktor penentu keberhasilan pada KUD yang maju dan mandiri. Hasil kajian tersebut dapat dijadikan sebagai pedoman karena faktor-faktor tersebut mempunyai pengaruh langsung maupun tidak langsung pada tingkat keberhasilan KUD.

Lima indikator penting sebagai penggerak internal organisasi KUD (faktor endogen) untuk mencapai keberhasilan yaitu 1) keberhasilan usaha, 2) pencapaian target, 3) pelayanan kepada anggota, 4) partisipasi anggota, dan 5) keanggotaan. Seluruh indikator tersebut berinteraksi satu sama lain dan dipengaruhi oleh faktor luar sehingga dihasilkan keragaan KUD. Sebagai wadah perekonomian pedesaan, KUD belum dapat diandalkan dan sebagian besar masih sangat bersandar pada program pemerintah. Perencanaan yang dibuat cenderung berorientasi pada program pemerintah yang akan dilaksanakan, serta tidak berdasarkan kepada kepentingan usaha para anggotanya.

Tingkat keberhasilan usaha KUD dipengaruhi oleh kinerja finansial dan kinerja operasional yang hanya dapat diukur melalui variabel indikatornya. Keberhasilan usaha adalah fungsi dari kinerja finansial, kinerja operasional, dan variabel eksogen (Tabel 1). Penelitian ini dilakukan untuk mendapatkan faktor-faktor kunci keberhasilan KUD serta menentukan besar pengaruh masingmasing variabel tersebut terhadap kemandirian KUD. Untuk mencapai tujuan tersebut dapat digunakan metode Structural Equation Modelling (SEM). Menurut Joreskog \& Sorbom (1989), SEM terdiri atas dua bagian yang saling berhubungan yaitu model pengukuran dan model persamaan struktural dengan variabel laten. Model pengukuran menjelaskan bagaimana variabel laten tergantung atau diindikasikan oleh variabel teramati, juga menggambarkan hubungan antara variabel indikator (teramati) dengan variabel tidak teramati yang dibangunnya. Dengan demikian penelitian ini dapat menghasilkan informasi dalam upaya mencari solusi optimal dalam pemberdayaan KUD ke arah kemandirian.

\section{BAHAN DAN METODE}

\section{Pengumpulan dan Pengolahan Data}

Data dan informasi dikumpulkan untuk dianalisis dengan menggunakan metode SEM untuk mengetahui sejauh mana peranan variabel yang diamati dalam manajemen KUD. Sampel penelitian adalah KUD dengan kriteria 1) sudah berjalan minimum lima tahun dengan prestasi baik, 2) bergerak dalam pengembangan usaha dan pelayanan anggotanya, 3) Anggota KUD merasa memiliki dan dilayani dengan baik oleh KUD dan 4) menjalankan serba usaha. Pengumpulan data dilakukan dalam kurun waktu dua bulan di daerah Kabupaten Garut, Jawa Barat. Data dikumpulkan melalui pengisian 118 kuesioner disertai wawancara kepada pengurus dan anggota KUD.

\section{Model Strukturisasi Sistem}

Indikator yang diperlukan dihimpun dari berbagai referensi yang disajikan pada Tabel 1. Empat komponen faktor laten eksogen yang dianalisis 1) Sumber daya KUD yang terdiri atas kunjungan pembina, potensi pengembangan usaha, potensi sumber daya, dan kemampuan pengelola. 2) Humanware (Komponen teknologi) yang terdiri atas kreativitas tenaga kerja, orientasi prestasi, orientasi afiliasi, kewirausahaan, dan orientasi integritas waktu. 3) Infoware (Dokumen fakta) yang terdiri atas akses informasi, keterkaitan informasi, dan kemampuan berkomunikasi. 4) Orgaware (Kerangka kerja organisasi) yang terdiri atas kepemimpinan, otonomi dalam sistem kerja, pengarahan, keterlibatan organisasi, iklim inovasi, dan kepatuhan KUD. 
Tabel 1. Indikator kunci pada usaha KUD

\begin{tabular}{|c|c|}
\hline Faktor* & Indikator * \\
\hline \multirow[t]{7}{*}{ Kinerja Finansial } & 1. Keuntungan kotor \\
\hline & 2. Modal kerja dibanding aset total \\
\hline & 3. Ratio utang terhadap Sisa Hasil Usaha \\
\hline & 4. Jangka waktu penerimaan hasil penjualan \\
\hline & 5. Nilai jual dibanding aset total \\
\hline & 6. Pembagian Sisa Hasil Usaha \\
\hline & 7. Perputaran modal \\
\hline \multirow[t]{5}{*}{ Kinerja Operasional } & 1. Kualitas pelayanan kepada anggota \\
\hline & 2. Sumber daya manusia \\
\hline & 3. Inovasi teknologi \\
\hline & 4. Pemenuhan kapasitas produksi \\
\hline & 5. Tingkat pertumbuhan keanggotaan \\
\hline \multirow[t]{7}{*}{ Keberhasilan Usaha } & 1. Profit Margin \\
\hline & 2. Rentabilitas Ekonomis \\
\hline & 3. Kepuasan \\
\hline & 4. Pencapaian Target \\
\hline & 5. Pertumbuhan produktivitas \\
\hline & 6. Partisipasi anggota \\
\hline & 7. Keanggotaan \\
\hline \multirow[t]{4}{*}{ Kunjungan pembina } & 1. Frekuensi kunjungan dari pembina \\
\hline & 2. Lama kunjungan \\
\hline & 3. Materi pembinaan \\
\hline & 4. Jumlah pembina yang berkunjung \\
\hline \multirow[t]{5}{*}{ Potensi pengembangan usaha } & 1. Bantuan program \\
\hline & 2. Pangsa pasar \\
\hline & 3. Pemasaran \\
\hline & 4. Penelitian dan pengembangan \\
\hline & 5. Usaha anggota \\
\hline \multirow[t]{6}{*}{ Potensi sumberdaya } & 1. Jumlah penduduk dalam wilayah kerja KUD \\
\hline & 2. Tersedianya infrastruktur \\
\hline & 3. Pasokan bahan baku \\
\hline & 4. Tingkat pendidikan anggota \\
\hline & 5. Sarana transportasi \\
\hline & 6. Sarana produksi \\
\hline \multirow[t]{8}{*}{ Kemampuan pengelola } & 1. Pengalaman dalam berkoperasi \\
\hline & 2. Pelatihan \\
\hline & 3. Kecerdasan \\
\hline & 4. Motivasi \\
\hline & 6. Inisiatif \\
\hline & 7. Kepuasan \\
\hline & 8. Tingkat pendidikan formal \\
\hline & 9. Bantuan manajer \\
\hline \multirow[t]{5}{*}{ Usaha anggota } & 1.Jenis usaha anggota yang sejalan dengan unit usaha KUD \\
\hline & 2. Jumlah usaha berdasarkan komoditas \\
\hline & 3. Kemampuan permodalan usaha anggota \\
\hline & 4. Kemampuan pemasaran \\
\hline & 5. Kualitas produk \\
\hline
\end{tabular}




\begin{tabular}{|c|c|}
\hline Faktor* & Indikator * \\
\hline Orientasi prestasi & $\begin{array}{l}\text { 1. Suka tantangan dan bertanggungjawab } \\
\text { 2. Penetapan tujuan prestasi } \\
\text { 3. Kebutuhan umpan balik } \\
\text { 4. Keterampilan perencanaan jangka panjang }\end{array}$ \\
\hline Orientasi afiliasi & $\begin{array}{l}\text { 1. Rasa berguna bagi kelompok } \\
\text { 2. Bertanggungjawab } \\
\text { 3. Menjaga persahabatan dan kerjasama } \\
\text { 4. Pelaksanaan tugas secara efektif }\end{array}$ \\
\hline Kewirausahaan & $\begin{array}{l}\text { 1. Keinginan untuk bereksperimen } \\
\text { 2. Kesediaan menerima perubahan } \\
\text { 3. Kemampuan melakukan inisiatif } \\
\text { 4. Keberanian menanggung risiko }\end{array}$ \\
\hline Orientasi integritas waktu & $\begin{array}{l}\text { 1. Kedisiplinan bekerja } \\
\text { 2. Orientasi target yang terukur } \\
\text { 3. Orientasi masa depan }\end{array}$ \\
\hline Akses informasi & $\begin{array}{l}\text { 1. Jenis sumber informasi } \\
\text { 2. Banyaknya informasi } \\
\text { 3. Pemanfaatan informasi } \\
\text { 4. Metode pengumpulan informasi } \\
\text { 5. Tingkat teknologi informasi } \\
\text { 6. Melalui pembinaan dari instansi terkait }\end{array}$ \\
\hline Keterkaitan informasi & $\begin{array}{l}\text { 1. Klasifikasi informasi } \\
\text { 2. Informasi internal } \\
\text { 3. Informasi eksternal } \\
\text { 4. Validitas informasi dan data } \\
\text { 5. Kemudahan mendapatkan informasi } \\
\text { 6. Biaya untuk memperoleh informasi }\end{array}$ \\
\hline Kemampuan berkomunikasi & $\begin{array}{l}\text { 1. Saluran komunikasi } \\
\text { 2. Kepercayaan terhadap sumber informasi } \\
\text { 3. Nilai informasi terhadap perusahaan } \\
\text { 4. Kuantitas informasi yang dikumpulkan } \\
\text { 5. Umpan balik }\end{array}$ \\
\hline Kepemimpinan & $\begin{array}{l}\text { 1. Gaya kepemimpinan } \\
\text { 2. Motivasi diri dan dorongan berprestasi } \\
\text { 3. Kecerdasan } \\
\text { 4. Kedewasaan } \\
\text { 5. Keluasan hubungan sosial } \\
\text { 6. Inisiatif }\end{array}$ \\
\hline Otonomi dalam sistem kerja & $\begin{array}{l}\text { 1. Pendelegasian tugas dan tanggungjawab } \\
\text { 2. Sistem kerja informal } \\
\text { 3. Kemandirian bekerja }\end{array}$ \\
\hline Pengarahan & $\begin{array}{l}\text { 1. Ketepatan waktu } \\
\text { 2. Perencanaan } \\
\text { 3. Pemikiran strategis } \\
\text { 4. Pengawasan kinerja }\end{array}$ \\
\hline Keterlibatan organisasi & $\begin{array}{l}\text { 1. Potensi kemitraan } \\
\text { 2. Kebanggaan dlm kemitraan } \\
\text { 3. Peluang pengembangan } \\
\text { 4. Kepatuhan pegawai terhadap peraturan } \\
\text { 5. Evaluasi kinerja kemitraan }\end{array}$ \\
\hline
\end{tabular}




\begin{tabular}{ll}
\hline \multicolumn{1}{c}{ Faktor* } & \multicolumn{1}{c}{ Indikator * } \\
\hline Iklim inovasi & 1. Evaluasi kinerja perusahaan \\
& 2. Orientasi penelitian dan pengembangan \\
& 3. Orientasi teknologi \\
4. Kepekaan terhadap perubahan lingkungan bisnis \\
\hline Kepatuhan KUD & 1. Kejujuran \\
& 2. Kepercayaan \\
3. Komunikasi terbuka & 4. Keadilan \\
5. Keinginan bermitra \\
6. Keseimbangan insentif dan risiko
\end{tabular}

Keterangan: *diolah dari berbagai referensi

\section{HASIL DAN PEMBAHASAN}

\section{Variabel Laten Endogen}

Berdasarkan hasil analisis variabel laten endogen yang terdiri dari kinerja finansial dan kinerja operasional, dari tujuh indikator yang menerangkan kinerja finansial diperoleh dua indikator yang berpengaruh kuat yaitu keuntungan kotor dan nilai jual dibanding aset total. Hal ini dapat dijelaskan bahwa KUD adalah lembaga ekonomi yang multipurpose, tidak hanya bertujuan untuk mencari keuntungan finansial tetapi juga bertujuan untuk meningkatkan kesejahteraan para anggotanya. Estimasi nilai jual dibandingkan aset total bertanda negatif $(-0,27)$, membuktikan peningkatan rasio antara nilai jual dan pemilikan aset akan mengurangi kinerja finansial. Rasio yang semakin kecil berarti kepemilikan aset relatif besar. Semakin tinggi tingkat kepemilikan aset akan semakin tinggi tingkat kemampuan pelayanan kepada anggota.
Kinerja operasional dipengaruhi oleh lima indikator yang terkuat yaitu tingkat pertumbuhan keanggotaan, sumber daya manusia, kualitas pelayanan kepada anggota, pemenuhan kapasitas produksi, dan inovasi teknologi (Tabel 2). Terdapat keterkaitan yang erat di antara kelima indikator tersebut. Pertumbuhan keanggotaan merupakan salah satu bukti adanya kinerja operasional yang baik. Untuk itu diperlukan personil karyawan dan pengurus yang berkualitas sehingga dapat memberikan pelayanan kepada anggota dengan baik dan berkualitas, serta dapat mengadopsi teknologi baru. Pengelolaan unit-unit usaha KUD yang berhasil umumnya dijalankan oleh manajer yang terampil di bidangnya, dan berkualifikasi sarjana strata 1.

Berbeda dengan hasil penelitian yang dilakukan oleh Nasution (2002) bahwa keanggotaan berpengaruh negatif terhadap keberhasilan usaha dikarenakan komoditas barang dan jasa yang

Tabel 2. Koefisien dan sumbangan keragaman setiap variabel indikator untuk variabel endogen

\begin{tabular}{llcc}
\hline \multicolumn{1}{c}{ Variabel Endogen } & \multicolumn{1}{c}{ Indikator* } & Estimasi & Nilai-t \\
\hline Kinerja Finansial & \multicolumn{1}{c}{ 1.Keuntungan kotor } & 1,39 & 7,73 \\
& 2. Nilai jual dibanding aset total & $-0,27$ & $-2,01$ \\
\hline Kinerja Operasional & 1.Kualitas pelayanan kepada anggota & 0,40 & 2,78 \\
& 2.Sumber daya manusia & 0,71 & 5,00 \\
& 3.Inovasi teknologi & 0,33 & 2,31 \\
& 4.Pemenuhan kapasitas produksi & 0,38 & 2,65 \\
& 5.Tingkat pertumbuhan keanggotaan & 1,23 & 6,49 \\
\hline Keberhasilan Usaha & 1.Profit Margin & 0,82 & 5,07 \\
& 2.Rentabilitas Ekonomis & 0,82 & 5,07 \\
& 3.Kepuasan & 0,96 & 5,59 \\
\hline
\end{tabular}

Keterangan: ${ }^{*}$ Indikator dalam tabel adalah indikator terpilih dengan pengaruh nyata dengan nilai-t $>1,96$ 
diusahakan KUD belum sepenuhnya terkait langsung usaha individu anggotanya. Melalui pendekatan yang berbeda, penelitian ini dilakukan dengan memilih contoh KUD-KUD dengan capaian keragaan yang baik dan ternyata komoditas barang dan jasa yang dihasilkan terkait erat dengan usaha anggotanya. Dengan demikian kondisi tersebut menguatkan bahwa untuk mencapai keberhasilan KUD komoditas barang dan jasa yang dihasilkan sebaiknya berkaitan erat dengan usaha anggotanya.
Analisis keberhasilan usaha KUD yang dibangun berdasarkan tujuh indikator menghasilkan tiga indikator yang berpengaruh kuat yaitu kepuasan, profit margin, dan rentabilitas ekonomis (Tabel 2). Hasil survei tingkat kepuasan menyatakan bahwa para responden agak puas sampai dengan tingkat puas terhadap kinerja KUD. Profit margin cukup tinggi berkisar antara $27 \%$ - $28 \%$ dan dengan rentabilitas sebesar $2 \%-11 \%$.

Tabel 3. Koefisien dan sumbangan keragaman variabel indikator untuk sumberdaya KUD

\begin{tabular}{|c|c|c|c|}
\hline $\begin{array}{l}\text { Sumber Daya } \\
\text { KUD }\end{array}$ & Indikator & Estimasi & Nilai-t * \\
\hline Kunjungan & 1.Frekuensi kunjungan pembina & 0,61 & 4,48 \\
\hline \multirow[t]{3}{*}{ pembina } & 2.Lama kunjungan & 0,76 & 5,61 \\
\hline & 3.Materi pembinaan & 0,58 & 4,27 \\
\hline & 4.Jumlah pembina yang berkunjung & 0,34 & 2,52 \\
\hline Potensi & 1.Bantuan program & 0,42 & 3,13 \\
\hline pengembangan & 2.Pangsa pasar & 0,55 & 4,05 \\
\hline \multirow[t]{2}{*}{ usaha } & 3.Pemasaran & 0,73 & 5,35 \\
\hline & 4.Penelitian dan pengembangan & 0,73 & 5,34 \\
\hline \multirow[t]{6}{*}{$\begin{array}{l}\text { Potensi } \\
\text { sumberdaya }\end{array}$} & $\begin{array}{l}\text { 1. Jumlah penduduk di wilayah kerja } \\
\text { KUD }\end{array}$ & 0,91 & 6,05 \\
\hline & 2.Tersedianya infrastruktur & 0,82 & 5,42 \\
\hline & 3.Pasokan bahan baku & 0,34 & 2,20 \\
\hline & 4.Tingkat pendidikan anggota & 0,66 & 4,31 \\
\hline & 5.Sarana transportasi & 0,57 & 3,73 \\
\hline & 6.Sarana produksi & 0,49 & 3,18 \\
\hline \multirow{8}{*}{$\begin{array}{l}\text { Kemampuan } \\
\text { pengelola }\end{array}$} & 1.Pengalaman dalam berkoperasi & 0,45 & 3,18 \\
\hline & 2.Pelatihan & 0,35 & 2,44 \\
\hline & 3.Kecerdasan & 0,90 & 6,85 \\
\hline & 4.Motivasi & 1,00 & 7,79 \\
\hline & 6.Inisiatif & 0,61 & 4,34 \\
\hline & 7.Kepuasan & 0,33 & 2,32 \\
\hline & 8.Tingkat pendidikan formal & 0,33 & 2,26 \\
\hline & 9. Bantuan manajer & 0,39 & 2,75 \\
\hline
\end{tabular}

Keterangan: *Indikator dalam tabel adalah indikator terpilih dengan pengaruh yata dengan nilai-t > 1,96

Tabel 4. Koefisien dan keragaman di dalam model struktural analisis sumber daya KUD

\begin{tabular}{|c|c|c|c|c|c|c|c|c|c|c|}
\hline \multirow[t]{2}{*}{ Variabel } & \multicolumn{2}{|c|}{$\begin{array}{c}\text { Kinerja } \\
\text { Finansial }\end{array}$} & \multicolumn{2}{|c|}{$\begin{array}{c}\text { Kinerja } \\
\text { Operasional }\end{array}$} & \multicolumn{2}{|c|}{$\begin{array}{c}\text { Kunjungan } \\
\text { Pembina }\end{array}$} & \multicolumn{2}{|c|}{$\begin{array}{c}\text { Potensi } \\
\text { Pengembangan }\end{array}$} & \multicolumn{2}{|c|}{$\begin{array}{l}\text { Kemampuan } \\
\text { Pengelola }\end{array}$} \\
\hline & $\beta$ & $\mathrm{T}$ & $\beta$ & $\mathrm{t}$ & $\beta$ & $\mathrm{t}$ & $\beta$ & $\mathrm{T}$ & $\beta$ & $\mathrm{T}$ \\
\hline $\begin{array}{l}\text { Kinerja } \\
\text { Finansial }\end{array}$ & - & - & 0,37 & 2,58 & 0,69 & 1,14 & 0,33 & 0,56 & $-1,05$ & $-0,99$ \\
\hline $\begin{array}{l}\text { Kinerja } \\
\text { Operasional }\end{array}$ & - & - & - & - & - & - & 0,31 & 2,39 & 0,41 & 3,21 \\
\hline SHU & 0,56 & 3,72 & 0,23 & 1,88 & - & - & - & - & - & - \\
\hline
\end{tabular}

Keterangan: Nilai tercetak tebal adalah nyata (nilai- $\mathrm{t}>1,96)$ 
Variabel Laten Eksogen

a. Sumber Daya KUD

Efektivitas kunjungan pembina dan potensi pengembangan usaha masing-masing ditentukan berdasarkan empat indikator, sedangkan pemanfaatan potensi sumber daya dan kemampuan pengelolaan KUD diukur oleh masing-masing enam dan sembilan indikator (Tabel 3). Hasil perhitungan menunjukkan bahwa kunjungan pembina dan potensi pengembangan usaha berpengaruh positif terhadap kinerja finansial KUD.

Tabel 4 memperlihatkan bahwa kinerja finansial dan kinerja operasional berpengaruh positif terhadap keberhasilan usaha KUD. Hal tersebut diitunjukkan dengan nilai estimasi sebesar 0,59 dan 0,24 .

\section{b. Komponen Humanware}

Komponen humanware yang terdiri dari lima variabel yaitu kreativitas tenaga kerja, orientasi prestasi, orientasi afiliasi, kewirausahaan, dan orientasi integritas waktu, masing-masing dipengaruhi secara nyata oleh tiga sampai empat indikator (Tabel 5). Kemampuan teknis adalah indikator yang paling berpengaruh terhadap kreativitas tenaga kerja. Indikator lainnya seperti keterampilan jangka panjang, menjaga persahabatan dan kerjasama, keinginan untuk bereksperimen, serta orientasi masa depan adalah indikatorindikator terkuat pengaruhnya terhadap masingmasing variabel. Pelaksanaan kegiatan berdasarkan perencanaan dengan penetapan tujuan prestasi telah dilaksanakan dengan baik, disiplin, suka tantangan

Tabel 5. Koefisien dan sumbangan keragaman setiap variabel indikator untuk humanware

\begin{tabular}{llcc}
\hline \multicolumn{1}{c}{$\begin{array}{c}\text { Komponen } \\
\text { Humanware }\end{array}$} & \multicolumn{1}{c}{ Indikator* } & Estimasi & Nilai-t \\
\hline Kreativitas Tenaga & 1. Kreativitas & 0,66 & 4,85 \\
kerja & 2. Kemampuan teknis & 0,82 & 5,97 \\
& 3. Inisiatif & 0,53 & 3,91 \\
& 4. Motivasi & 0,38 & 2,80 \\
\hline Orientasi prestasi & 1. Suka tantangan, bertanggungjawab & 0,38 & 2,80 \\
& 2. Penetapan tujuan prestasi & 0,54 & 3,96 \\
& 3. Kebutuhan umpan balik & 0,70 & 5,08 \\
& 4. Keterampilan perencanaan jangka panjang & 0,77 & 5,58 \\
\hline Orientasi afiliasi & 1. Bertanggungjawab & 0,90 & 5,76 \\
& 2. Menjaga persahabatan dan kerjasama & 0,97 & 6,10 \\
& 3. Pelaksanaan tugas secara efektif & 0,32 & 2,05 \\
\hline Kewirausahaan & 1. Keinginan untuk bereksperimen & 1,40 & 4,91 \\
& 2. Kesediaan menerima perubahan & 0,50 & 3,93 \\
& 3. Kemampuan melakukan inisiatif & 0,47 & 3,63 \\
& 4. Keberanian menanggung risiko & 0,29 & 2,19 \\
\hline Orientasi integritas & 1. Kedisiplinan bekerja & 0,30 & 2,03 \\
waktu & 2. Orientasi target yang terukur & 0,92 & 6,68 \\
& 3. Orientasi masa depan & 0,98 & 7,13 \\
\hline
\end{tabular}

Keterangan: *Indikator dalam tabel adalah indikator terpilih dengan pengaruh nyata dengan nilai- $\mathbf{t}>1,96$

Tabel 6. Koefisien dan keragaman di dalam model struktural komponen humanware

\begin{tabular}{|c|c|c|c|c|c|c|c|c|c|c|}
\hline \multirow[t]{2}{*}{ Variabel } & \multicolumn{2}{|c|}{ Kreativitas } & \multicolumn{2}{|c|}{$\begin{array}{c}\text { Orientasi } \\
\text { Prestasi }\end{array}$} & \multicolumn{2}{|c|}{$\begin{array}{l}\text { Kewira- } \\
\text { usahaan }\end{array}$} & \multicolumn{2}{|c|}{$\begin{array}{c}\text { Orientasi } \\
\text { Afiliasi }\end{array}$} & \multicolumn{2}{|c|}{$\begin{array}{l}\text { Orientasi } \\
\text { Waktu }\end{array}$} \\
\hline & $\beta$ & $\mathrm{T}$ & $\mathrm{B}$ & $\mathrm{T}$ & $\mathrm{B}$ & $\mathrm{t}$ & $\beta$ & $\mathrm{t}$ & $\mathrm{B}$ & $\mathrm{t}$ \\
\hline Kinerja Finansial & 0,44 & 1,24 & $-0,16$ & $-0,47$ & 0,32 & 1,93 & - & - & - & - \\
\hline Kinerja Operasional & - & - & - & - & - & - & 0,36 & 2,60 & 0,39 & 2,92 \\
\hline SHU & 0,59 & 4,24 & 0,24 & 2,03 & - & - & & & & \\
\hline
\end{tabular}

Keterangan: Nilai yang tercetak tebal adalah nyata (nilai-t $>1,96$ ) 
dan bertanggung jawab, serta berani menanggung resiko.

Evaluasi setelah melaksanakan kegiatan yang merupakan kebutuhan umpan balik dijalankan dengan baik melalui laporan pertanggungjawaban yang disampaikan secara rutin pada Rapat Anggota Tahunan. Hal ini dapat dilaksanakan dengan baik karena juga ditunjang oleh kemampuan teknis yang baik, kreativitas yang cukup, inisiatif yang baik, dan motivasi tinggi dari seluruh tenaga kerja.

\section{c. Infoware}

Seluruh nilai koefisien dari 16 variabel indikator komponen infoware adalah positif (Tabel 7), berarti 16 variabel tersebut berpengaruh positif terhadap masing-masing variabel laten-nya. Variabel akses informasi lebih berpengaruh positif terhadap variabel kinerja operasional. Informasi yang beragam, banyak dan dimanfaatkan dengan baik akan berpengaruh terhadap peningkatan kinerja pengelolaan KUD.

Indikator terkuat dari komponen kemampuan komunikasi adalah umpan balik, yang akan berpengaruh kuat terhadap kinerja finansial (Tabel 7). Perolehan informasi tentang hasil kegiatan akan menambah motivasi bekerja dan mendorong melakukan perbaikan segera bila terjadi kesalahan maupun kekurangan. Namun, akses terhadap informasi dan keterkaitan informasi dengan kepentingan KUD berpengaruh lemah terhadap kinerja finansial.

\section{d. Orgaware}

Hasil analisis orgaware (Tabel 8) menunjukkan kinerja finansial dan kinerja operasional dipengaruhi secara kuat hanya oleh otonomi kerja dengan estimasi masing-masing 0,61 dan 0,69. KUD adalah pelaku ekonomi dengan berbagai jenis kegiatan usaha yang dikelompokkan ke dalam unit-unit usaha tertentu sesuai dengan bidang usahanya.

Unit-unit usaha KUD mempunyai otonomi kerja yang tegas dan masing-masing unit dikelola oleh seorang manajer sehingga dapat mencapai prestasi yang baik. Kenyataan tersebut dibuktikan dengan adanya hasil analisis pada Tabel 9 bahwa otonomi kerja berpengaruh kuat terhadap kinerja finansial dan kinerja operasional. Elemen lain seperti kepemimpinan, pengarahan, keterlibatan organisasi, iklim inovasi, dan kepatuhan KUD terhadap tata tertib organisasi, berpengaruh lemah terhadap kinerja finansial dan operasional.

Tabel 7. Koefisien dan sumbangan keragaman setiap variabel indikator untuk inforware

\begin{tabular}{llcc}
\hline \multicolumn{1}{c}{$\begin{array}{c}\text { Komponen } \\
\text { Inforware }\end{array}$} & \multicolumn{1}{c}{ Indikator* } & Estimasi & Nilai-t \\
\hline Akses informasi & 1. Jenis sumber informasi & 0,88 & 5,73 \\
& 2. Banyaknya informasi & 0,83 & 5,69 \\
& 3. Pemanfaatan informasi & 0,48 & 3,14 \\
& 4. Tingkat teknologi informasi & 0,31 & 2,01 \\
& 5. Melalui pembinaan dari instansi terkait & 0,56 & 3,71 \\
\hline Keterkaitan & 1. Klasifikasi informasi & 0,67 & 4,85 \\
informasi & 2. Informasi internal & 0,86 & 6,44 \\
& 3. Informasi eksternal & 0,34 & 2,30 \\
& 4. Kemudahan mendapatkan informasi & 0,60 & 4,26 \\
\hline Kemampuan & 1. Saluran komunikasi & 0,36 & 2,73 \\
Berkomunikasi & 2. Kuantitas informasi yang dikumpulkan & 0,41 & 3,13 \\
& & & \\
& 3. Umpan balik & 1,40 & 4,91 \\
\hline
\end{tabular}

Keterangan: *Indikator dalam tabel adalah indikator terpilih dengan pengaruh nyata dengan nilai-t $>1,96$ 
Tabel 8. Koefisien dan sumbangan keragaman setiap variabel indikator untuk orgaware

\begin{tabular}{llcc}
\hline $\begin{array}{c}\text { Komponen } \\
\text { Orgaware }\end{array}$ & \multicolumn{1}{c}{ Indikator } & Estimasi & Nilai-t * \\
\hline Kepemimpinan & 1. Gaya kepemimpinan & 0,63 & 4,63 \\
& 2. Motivasi diri dan dorongan berprestasi & 0,81 & 6,13 \\
& 3. Kecerdasan & 0,55 & 4,07 \\
& 4. Kedewasaan & 0,28 & 2,01 \\
& 5. Keluasan hubungan sosial & 0,59 & 7,35 \\
& 6. Inisiatif & 0,62 & 4,57 \\
\hline Otonomi dalam & 1. Pendelegasian tugas dan tanggungjawab & 0,64 & 4,53 \\
sistem kerja & 2. Sistem kerja informal & 0,88 & 6,39 \\
& 3. Kemandirian bekerja & 0,33 & 2,23 \\
\hline Pengarahan & 1. Ketepatan waktu & 0,91 & 2,51 \\
& 2. Perencanaan & 0,37 & 2,51 \\
& 3. Pemikiran strategis & 0,71 & 5,04 \\
& 4. Pengawasan kinerja & 0,37 & 2,51 \\
\hline Keterlibatan & 1. Potensi kemitraan & 0,72 & 5,22 \\
organisasi & 2. Peluang pengembangan & 0,64 & 4,59 \\
& 3. Kepatuhan pegawai terhadap peraturan & 0,98 & 7,47 \\
& 4. Evaluasi kinerja kemitraan & 1,04 & 8,04 \\
\hline Iklim inovasi & 1. Evaluasi kinerja perusahaan & 0,63 & 4,49 \\
& 2. Orientasi penelitian dan pengembangan & 0,41 & 2,86 \\
& 3. Kepekaan terhadap perubahan lingkungan bisnis & 0,27 & 2,84 \\
\hline Kepatuhan KUD & 1. Komunikasi terbuka & 0,88 & 6,75 \\
& 2. Keadilan & 0,76 & 5,73 \\
& 3. Keinginan bermitra & 0,85 & 6,46 \\
\hline
\end{tabular}

Keterangan:

*Indikator dalam tabel adalah indikator terpilih dengan pengaruh nyata dengan nilai- $\mathrm{t}>1,96$

Tabel 9. Koefisien dan Keragaman di dalam Model Struktural Analisis Orgaware

\begin{tabular}{|c|c|c|c|c|c|c|c|c|c|c|c|c|c|c|c|c|}
\hline \multirow[t]{2}{*}{ Variabel } & \multicolumn{2}{|c|}{$\begin{array}{c}\text { Kinerja } \\
\text { Finansial }\end{array}$} & \multicolumn{2}{|c|}{$\begin{array}{c}\text { Kinerja } \\
\text { Operasional }\end{array}$} & \multicolumn{2}{|c|}{$\begin{array}{l}\text { Kepemim- } \\
\text { pinan }\end{array}$} & \multicolumn{2}{|c|}{$\begin{array}{c}\text { Otonomi } \\
\text { kerja }\end{array}$} & \multicolumn{2}{|c|}{ Pengarahan } & \multicolumn{2}{|c|}{ Keterlibatan } & \multicolumn{2}{|c|}{ Inovasi } & \multicolumn{2}{|c|}{ Kepatuhan } \\
\hline & $\beta$ & $\mathrm{t}$ & B & $\mathrm{t}$ & $\beta$ & $\mathrm{t}$ & $\beta$ & $\mathrm{t}$ & $\beta$ & $\mathrm{t}$ & $\beta$ & $\mathrm{t}$ & $\beta$ & $\mathrm{t}$ & $\beta$ & $\mathrm{t}$ \\
\hline $\begin{array}{l}\text { Kinerja } \\
\text { Finan- } \\
\text { sial }\end{array}$ & - & - & - & - & 1,15 & 1,81 & 0,61 & 2,85 & 0,61 & 1,28 & - & - & $-0,62$ & $-0,89$ & $-0,66$ & $\begin{array}{l}- \\
1,11\end{array}$ \\
\hline $\begin{array}{l}\text { Kinerja } \\
\text { Opera- } \\
\text { sional }\end{array}$ & - & - & - & - & - & - & 0,69 & 3,22 & - & - & $-0,03$ & $-0,21$ & - & - & - & - \\
\hline SHU & 0,57 & 3,99 & 0,25 & 2,04 & - & - & - & - & - & - & - & - & - & - & - & - \\
\hline
\end{tabular}

Keterangan: nilai yang tercetak tebal adalah nyata pengaruhnya terhadap variabel teramati (nilai- $t>1,96)$

\section{SIMPULAN}

1. Tingkat keberhasilan KUD ditentukan oleh kinerja finansial dan kinerja operasional. Kinerja finansial ditentukan oleh keuntungan kotor, serta rasio nilai jual dibanding aset total, sedangkan kinerja operasional ditentukan oleh kualitas pelayanan kepada anggota, sumber daya manusia, inovasi teknologi, pemenuhan kapasitas produksi, dan tingkat pertumbuhan keanggotaan.
2. Potensi sumber daya, komponen humanware, infoware dan orgaware merupakan variabelvariabel yang berpengaruh tidak langsung terhadap tingkat keberhasilan KUD. Potensi sumber daya KUD dipengaruhi oleh variabel kunci yang terdiri atas: potensi pengembangan usaha dan kemampuan pengelola. Variabelvariabel kunci dari komponen humanware adalah: bertanggungjawab, menjaga persahabatan dan kerjasama, pelaksanaan tugas secara efektif, 
Variabel-variabel kunci dari komponen inforware adalah: saluran komunikasi, kuantitas informasi yang dikumpulkan, dan umpan balik. Variabel-variabel kunci dari komponen orgaware adalah: pendelegasian tugas dan tanggungjawab, sistem kerja informal, dan kemandirian bekerja.

3. Hasil analisis hubungan antara variabel kunci dan besar pengaruhnya terhadap keberhasilan usaha KUD dapat menentukan tingkat kepentingan variabel tersebut dalam pengelolaan KUD sehingga dapat dijadikan pedoman dalam upaya pemberdayaan KUD ke arah kemandirian.

\section{UCAPAN TERIMA KASIH}

Atas terselenggaranya penelitian ini, kami sampaikan terima kasih kepada $\mathrm{DP}_{2} \mathrm{M}$ Dikti yang telah menyediakan dana melalui program penelitian Fundamental tahun 2008. Terimakasih untuk bantuan Dinas Koperasi dan Pasar Kabupaten Garut, Para Pengurus KUD di Kabupaten Garut terutama KUD yang ditunjuk sebagai contoh penelitian sehingga penelitian dapat berjalan lancar dan sesuai rencana.

\section{DAFTAR PUSTAKA}

Antara, M dan Komenaung AG. 2010. Kinerja Koperasi Unit Desa di Provinsi Bali: Pendekatan Structural Equation Model. http://www.docstoc.com. Diakses: 25 Februari 2010.

Bollen, KA. 1989. Structural Equations with Latent Variables. New York: John Wiley \& Sons. 512 hal.

Firdaus, M dan Susanto AE. 2002. Perkoperasian: Sejarah, Teori dan Praktek. Jakarta: Ghalia Indonesia. 142 hal.

Gumbira-Sa'id, E, Rachmayanti dan Z Muttaqin. 2001. Manajemen Teknologi Agribisnis. Jakarta: Penerbit Ghalia Indonesia. 151 hal.

Joreskog, K and Sorbom D. 1989. LISREL 8.: User's Reference Guide. Mooresville: Scientific Software International. 378 hal.

Koperasi Unit Desa (KUD). 2007. Laporan Tahunan. Garut: Koperasi Unit Desa.

Mangkuprawira, TS. 2003. Manajemen Sumber Daya Manusia Strategik. Jakarta: Ghalia Indonesia. 254 hal.

Nasution, M. 2002. Pengembangan Kelembagaan Koperasi Pedesaan untuk Agroindustri. Eriyatno, Sulaeman S, Soemarta ID, Sujana JG, editor. Bogor: IPB-Press. 284 hal.

Oktolepal, H. 2009. Hubungan Persepsi Anggota KUD Terhadap Fungsi-fungsi Kepemimpinan Pengurus KUD dengan Peranan Anggota KUD Mina Jaya dan KUD Mina Lestari. http://www.pustakailmiah.unila.ac.id. Diakses 25 Februari 2010.

Undang-undang Nomor 25 Tahun 1992 tentang Perkoperasian. 